\title{
PEMBELAJARAN MATEMATIKA BERBASIS GOOGLE SUITE FOR EDUCATION UNTUK MENINGKATKAN KECAKAPAN KOLABORATIF SISWA
}

\author{
Abi Talib ${ }^{1}$, Suaedi², Muhammad llyas ${ }^{3}$ \\ 1,2,3 Universitas Cokroaminoto Palopo, Jl. Latamacelling, Tompotika, Wara, Palopo, Sulawesi Selatan, Indonesia \\ E-mail: ${ }^{1}$ abi.talib@yps.sch.id, ${ }^{2}$ suaedif@gmail.com, ${ }^{3}$ muhammadilyas@uncp.ac.id
}

\begin{abstract}
This study aims to find out the extent to which google suite for education-based mathematics learning can improve the collaborative proficiency of grade VI students of SD YPS Singkole. The research time was conducted in the odd semester of 2020/2021. This study is a quasi-experimental study with a selected experimental unit of 30 grade VI students at SD YPS Singkole. Determination of experimental units using a purposive sampling method. The instruments in this study are the student activity observation sheet, learning implementation observation sheet, student response questionnaire, and collaborative proficiency observation sheet. The data analysis techniques used are descriptive analysis and inferential analysis. The results of this study are: (1) students' activities in google suite for education-based mathematics learning are in the active category; (2) the implementation of google suite for education-based mathematics learning is in the category of very well executed; (3) students' response to google suite for education-based mathematics learning is in a positive category; (4) the collaborative proficiency skills of grade VI students of SD YPS Singkole Year 2020/2021 in google suite for education-based mathematics learning are in the excellent category; and (5) google suite for education-based mathematics learning can improve the collaborative proficiency of grade VI students of SD YPS Singkole Year 2020//2021 with high classification.
\end{abstract}

Keywords: Google suite for education, collaborative skills, math learning

\section{ABSTRAK}

Penelitian ini bertujuan untuk mengetahui sejauh mana pembelajaran matematika berbasis google suite for education dapat meningkatkan kecakapan kolaboratif siswa kelas VI SD YPS Singkole. Waktu penelitian dilaksanakan pada Semester Ganjil Tahun Pelajaran 2020/2021. Penelitian ini merupakan penelitian kuasi eksperimen dengan satuan eksperimen yang dipilih berjumlah 30 siswa kelas VI di SD YPS Singkole. Penentuan satuan eksperimen dengan menggunakan metode purposive sampling. Instrumen pada penelitian ini adalah lembar observasi aktivitas siswa, lembar observasi keterlaksanaan pembelajaran, angket respon siswa, dan lembar observasi kecakapan kolaboratif. Teknik analisis data yang digunakan adalah analisis deskriptif dan analisis inferensial. Hasil penelitian ini adalah: (1) aktivitas siswa dalam pembelajaran matematika berbasis google suite for education berada pada kategori aktif; (2) keterlaksanaan pembelajaran matematika berbasis google suite for education berada pada kategori terlaksana dengan sangat baik; (3) respon siswa terhadap pembelajaran matematika berbasis google suite for education berada pada kategori positif; (4) kemampuan kecakapan kolaboratif siswa kelas VI SD YPS Singkole Tahun Pelajaran 2020/2021 pada pembelajaran matematika berbasis google suite for education berada pada kategori sangat baik; dan (5) pembelajaran matematika berbasis google suite for education dapat meningkatkan kecakapan kolaboratif siswa kelas VI SD YPS Singkole Tahun Pelajaran 2020//2021 dengan klasifikasi tinggi.

Kata kunci: Google suite for education, kecakapan kolaboratif, pembelajaran matematika

Dikirim: 9 November 2020; Diterima: 30 Januari 2021; Dipublikasikan: 30 Maret 2021

Cara sitasi: Talib, A., Suaedi., \& llyas, M. (2021). Pembelajaran matematika berbasis google suite for education untuk meningkatkan kecakapan kolaboratif siswa. Teorema: Teori dan Riset Matematika, 6(1), 34-47.

Doi: http://dx.doi.org/10.25157/teorema.v6i1.4470 


\section{PENDAHULUAN}

Masyarakat saat ini berada pada keterbukaan informasi (information age) atau masyarakat ilmu pengetahuan (knowledge society) yang dilandasi oleh perkembangan komputer dan pemanfaatan jaringan internet sebagai salah satu sumber belajar tanpa batas ruang dan waktu. Hasil survei Asosiasi Penyelenggara Jaringan Internet Indonesia (APJII) menunjukkan bahwa pengguna internet di Indonesia selalu mengalami peningkatan dari tahun ke tahun. Pada tahun 2018 jumlah pengguna internet di Indonesia menembus angka 171,17 juta jiwa dari jumlah populasi 264 juta jiwa, atau sekitar $64,8 \%$. Angka ini mengalami peningkatan yang cukup signifikan jika dibandingkan dengan tahun 2017 dimana angka penetrasi internet di Indonesia tercatat sebesar 54,86\% (Izza, 2019).

Penggunaan teknologi berdampak pada perubahan pembelajaran tradisional khususnya pada pembelajaran matematika. Pergeseran strategi pembelajaran menuju pada pembelajaran berbasis teknologi informasi dan komunikasi saat ini sangat mudah ditemui dengan berbagai platform mulai dari model e-learning, smart classroom technology, virtual classroom, maupun blended learning (Hasbullah, 2014). Aplikasi yang dapat digunakan siswa dan guru dalam pembelajaran dari rumah pun beragam, beberapa diantaranya misalnya: rumah belajar, ruang guru, microsoft office 365 , google suite for education.

Salah satu ciri generasi $Z$ adalah akrab dengan teknologi, sehingga dapat dipastikan bahwa pengguna internet termasuk didalamnya adalah anak-anak yang masih duduk di bangku sekolah dasar (Izza, 2019). Hasil investigasi guru di kelas VI MA SD YPS Singkole menunjukkan bahwa dari 29 siswa, 20 diantaranya memiliki laptop atau komputer di rumah, bahkan seluruh siswa memiliki smartphone dan dapat mengakses internet dengan baik melalui wifi, indiehome atau paket data. Sayangnya, sebagian besar siswa masih memanfaatkan fasilitas tersebut untuk mengakses sosial media, game, dan hiburan lainnya. Guru sebagai fasilitator siswa dalam belajar dapat mengarahkan siswa untuk menggunakan berbagai fasilitas tersebut untuk menunjang kegiatan pembelajaran, baik di rumah maupun di sekolah. Pemanfaatan fasilitas belajar di rumah dan di sekolah dengan pendampingan orang tua dan guru sangat mungkin dimaksimalkan untuk mencapai pembelajaran yang bermakna serta mengembangkan berbagai keterampilan dan kecakapan hidup yang dibutuhkan berdasarkan tuntutan zaman dimana dunia pendidikan saat ini mulai disibukkan untuk menyiapkan generasi yang mampu bertahan dalam kompetisi di era revolusi industri 4.0 (Wijaya et al., 2016).

Teknologi digital saat ini merupakan tools utama dalam seluruh aktivitas manusia, termasuk pendidikan. Melalui rekayasa intelegensia dan internet of thing pada tahun 2010 memberikan kemudahan dalam beraktivitas secara efektif dan efesien (Cholily et al., 2019). Keberadaan teknologi memudahkan berlangsungnya proses pembelajaran dan mengakibatkan bergesernya paradigma pembelajaran dari model konvensional yang biasanya dilaksanakan dalam bentuk tatap muka secara langsung di ruang kelas menuju pada pembelajaran yang lebih fleksibel. Penyampaian pembelajaran maupun pemberian tugas kepada siswa dapat dilakukan guru dengan memanfaatkan media pembelajaran online (Risdianto, 2019).

Pemanfaatan teknologi informasi dan komunikasi (TIK) dalam pembelajaran menjadi sebuah keniscayaan pada masa pandemi Covid-19 saat ini, dimana pemerintah memutuskan untuk pelaksanaan pembelajaran jarak jauh (PJJ) khususnya yang dilaksanakan secara daring. Pengintegrasian TIK akan menghasilkan kebiasaan-kebiasaan baru dalam proses pembelajaran dimasa depan serta mendorong peningkatan literasi teknologi. Pelaksanan pembelajaran daring yang secara tiba-tiba mengakibatkan kurangnya kesiapan guru dan siswa dalam pemanfataan berbagai platform pembelajaran jarak jauh berbasis teknologi dan informasi. Pembelajaran daring yang dilakukan guru lebih pada metode ceramah melalui pertemuan virtual, sehingga pembelajaran didominasi oleh guru dan tidak berpusat pada siswa. Pembelajaran daring semacam ini pada akhirnya akan menyebabkan rendahnya kecakapan memecahkan masalah dalam kehidupan sehari-hari siswa, utamanya kecakapan yang menjadi tuntutan dalam pembelajaran abad 21 diantaranya kecakapan memecahkan masalah dan berpikir kritis, inovatif dan kreatif, serta kemampuan komunikasi dan kolaborasi (Gunawan \& Sunarman, 2018). 
Hasil pengamatan yang dilakukan oleh penulis selaku guru kelas VI di SD YPS Singkole, menunjukkan masih rendahnya kemampuan siswa dalam bekerja secara berkelompok atau kolaborasi dimana sebagian besar siswa dalam diskusi ataupun penugasan kelompok hanya menunggu jawaban dan tidak memberikan sumbangsih pemikiran, ide ataupun kontribusi lainnya. Hasil observasi awal menunjukkan guru hanya memanfaatkan diskusi dan pengiriman lembar kerja melalui WA group yang dibuat untuk setiap kelompok. Hal ini menunjukkan partisipasi siswa dalam diskusi maupun menyelesaikan tugas kelompok kurang dapat terpantau dengan baik, selain itu hanya anak-anak tertentu saja yang berperan dalam diskusi dan kerja kelompok yang dilakukan.

Kesenjangan ini semakin nampak dalam pelaksanaan pembelajaran daring, karena guru lebih banyak melaksanakan pembelajaran dengan metode ceramah yang dilakukan secara virtual meskipun sudah memanfaatkan media presentasi berupa power point. Meskipun guru telah difasilitasi dengan akun google suite namun dalam pemanfaatannya masih terbatas pada penggunaan google meet untuk pertemuan pembelajaran virtual, dan penggunaan classroom yang belum maksimal karena lebih banyak digunakan hanya sebagai media untuk memberi penugasan dan pengumpulan tugas bagi siswa. Padahal pemanfaatan fitur-fitur dalam google suite for education seperti google document, google slide, hangout, calender, google chat dan jamboard serta memaksimalkan google classroom sebagai Learning Management System (LMS) sangat memungkinkan untuk merancang pembelajaran yang berpusat pada siswa (student centered) dan mengembangkan keterampilan abad 21 yang diharapkan baik dalam pembelajaran singkron maupun asingkron (Herrick, 2010).

Google suite for education merupakan layanan untuk dunia pendidikan yang dipersembahkan oleh google yang dapat dijadikan sebagai salah satu solusi untuk komunikasi sehingga menjadi solusi berkolaborasi dalam kegiatan pembelajaran yang diharapkan mampu untuk meningkatkan dan mengasah kecakapan kolaboratif siswa. Kecakapan kolaborasi merupakan kecakapan bekerja bersama secara efektif dan menunjukkan rasa hormat kepada anggota tim yang beragam, melatih kelancaran dan kemauan dalam membuat keputusan yang diperlukan untuk mencapai tujuan bersama. Pada proses pembelajaran guru hendaknya menciptakan situasi dimana siswa dapat belajar bersama atau berkelompok (team work), sehingga tercipta suasana demokratis dimana siswa dapat belajar menghargai perbedaan pendapat, menyadari kesalahan yang dibuat, serta dapat memupuk rasa tanggung jawab, selain itu siswa belajar tentang kerjasama tim, kepemimpinan, ketaatan pada otoritas, dan fleksibilitas dalam lingkungan kerja. Siswa dapat dikatakan memiliki kecakapan berkolaborasi jika memenuhi 3 komponen kecakapan berkolaborasi meliputi: (1) mampu bekerja secara efektif dan menghargai anggota tim yang berbeda; (2) menunjukkan fleksibilitas dan keinginan untuk menjadi orang yang berguna dalam melakukan kompromi untuk mencapai tujuan umum; dan (3) memikul tanggung jawab dalam pekerjaan kolaboratif dan menghargai kontribusi dari setiap anggota tim (Hermawan et al., 2017).

Analisa yang telah dipaparkan memotivasi penulis untuk melakukan penelitian dengan tujuan mendeskripsikan aktivitas siswa, keterlaksanaan pembelajaran, dan respon siswa dalam pembelajaran matematika berbasis google suite for education, mendeskripsikan kemampuan kecakapan kolaboratif siswa pada pembelajaran matematika berbasis google suite for education, serta meningkatkan kecakapan kolaboratif siswa pada pembelajaran matematika berbasis google suite for education.

\section{METODE PENELITIAN}

Penelitian ini dilaksanakan di SD YPS Singkole. Waktu penelitian dilaksanakan pada Semester Ganjil Tahun Pelajaran 2020/2021. Jenis penelitian ini adalah pre-eksperimental dengan one-group pretest-posttest design. Perlakuan (treatment) yang dimaksud berupa pembelajaran matematika dengan pemanfaatan google suite for education untuk mengetahui pengaruhnya terhadap peningkatan kecakapan kolaboratif siswa. Populasi dalam penelitian ini adalah seluruh siswa kelas VI SD YPS Singkole pada Semester Ganjil Tahun Pelajaran 2020/2021 yang terdiri atas 5 rombongan 
belajar, yaitu kelas VI MM, VI MA, VI OC, VI IG dan VI AY. Penentuan sampel dalam penelitian sebanyak 30 siswa menggunakan metode purposive sampling.

Instrumen yang digunakan dalam penelitian ini, yaitu: (1) lembar observasi aktivitas siswa; (2) lembar observasi keterlaksanaan pembelajaran; (3) angket respon siswa; dan (4) lembar observasi kecakapan kolaboratif. Validitas instrumen diuji melalui lembaga Pusat Studi Pendidikan Pembelajaran dan Lesson Study (PSP2LS) Universitas Cokroaminoto Palopo dan divalidasi oleh dua orang ahli. Data dikumpulkan melalui observasi secara langsung oleh lima orang observer, setiap observer mengobservasi 1 kelompok siswa yang terdiri atas 6 siswa.

Teknik analisis data dalam penelitian ini meliputi:

1. Uji Prasyarat (Uji Normalitas)

Uji normalitas menggunakan kolmogorov-smirnov test. Hal ini untuk membuktikan bahwa data yang dipergunakan berdistribusi normal.

2. Analisis Deskriptif

a. Deskripsi hasil lembar observasi aktivitas siswa

Data yang diperoleh berdasarkan pengamatan observer dianalisis dan dideskripsikan dengan merujuk pada interval penentuan kategori efektivitas aktivitas siswa (Arsyad, 2016). Kategori keefektifan aktivitas siswa tercantum pada Tabel 1.

Tabel 1. Kategori keefektifan aktivitas siswa

\begin{tabular}{cc}
\hline Kriteria & Kategori \\
\hline $4,5 \leq \bar{x} \leq 5$ & Sangat aktif \\
$3,5 \leq \bar{x}<4,5$ & Aktif \\
$2,5 \leq \bar{x}<3,5$ & Cukup aktif \\
$1,5 \leq \bar{x}<2,5$ & Kurang aktif \\
$\bar{x}<1,5$ & Tidak aktif \\
\hline
\end{tabular}

Keterangan:

$\bar{x}=$ skor rata-rata aktivitas siswa

Kriteria yang digunakan untuk memutuskan aktivitas siswa memenuhi kriteria keefektifan jika nilai skor rata-rata minimal berada dalam kategori aktif $(3,5 \leq \bar{x}<4,5)$.

b. Deskripsi hasil lembar observasi keterlaksanaan pembelajaran

Kegiatan pengambilan data keterlaksanaan pembelajaran ini dilakukan selama proses pembelajaran berlangsung. Teknik analisis data keterlaksanaan pembelajaran menggunakan teknik analisis deskriptif dengan kriteria yang disajikan pada Tabel 2.

Tabel 2. Kriteria keterlaksanaan pembelajaran

\begin{tabular}{cc}
\hline Rata-rata $(\%)$ & Kategori \\
\hline $90-100$ & Sangat baik \\
$80-89$ & Baik \\
$65-79$ & Cukup baik \\
$55-64$ & Kurang baik \\
$0-54$ & Sangat kurang baik \\
\hline
\end{tabular}

c. Deskripsi hasil angket respon siswa

Data hasil respon siswa yang diperoleh melalui angket, selanjutnya dianalisis menggunakan statistik deskriptif dengan langkah-langkah sebagai berikut (Arsyad, 2016): (1) memberikan skor pada lembar hasil respon siswa yang sudah diisi oleh siswa; (2) merekapitulasi skor hasil pengisian sesudah tindakan, kemudian data diolah dengan menentukan rata-rata masing-masing item pertanyaan berdasarkan jawaban siswa; (3) selanjutnya untuk tiap-tiap item pertanyaan dilakukan perhitungan untuk memperoleh rata-rata total; dan (4) menentukan kategori respon siswa dengan mencocokkan hasil rata-rata total dengan kriteria yang ditetapkan. Kategori skor rata-rata respon siswa diinterpretasi mengacu pada Tabel 3. 
Tabel 3. Kategori respon siswa

\begin{tabular}{cc}
\hline Kriteria & Kategori \\
\hline $3,5 \leq \bar{x} \leq 4$ & Positif \\
$2,5 \leq \bar{x}<3,5$ & Cenderung positif \\
$1,5 \leq \bar{x}<2,5$ & Cenderung negatif \\
$\bar{x}<1,5$ & Negatif \\
\hline
\end{tabular}

Kriteria yang digunakan untuk menentukan respon siswa memenuhi keefektifan jika skor ratarata minimal berada dalam kategori cenderung positif.

d. Deskripsi hasil lembar observasi kecakapan kolaboratif

Analisis data hasil observasi kecakapan kolaboratif baik pengamatan awal sebelum perlakuan maupun pengamatan akhir setelah perlakuan melalui beberapa langkah sebagai berikut (Arsyad, 2016):

1) Mentabulasi semua data berbentuk skala Likert 1-5, yang diperoleh pada lembar observasi kecakapan kolaboratif.

2) Menghitung rerata ketercapaian kecakapan kolaboratif setiap indikator menggunakan rumus:

$\bar{X}=\frac{\sum x}{n}$

Keterangan:

$\bar{X}=$ Ketercapaian kecakapan kolaboratif

$\sum x=$ Jumlah skor yang diperoleh siswa

$n=$ Jumlah siswa

3) Menghitung persentase nilai dari peningkatan kecakapan kolaboratif.

4) Mengkonversi skor persentase menjadi data kualitatif dengan mengacu kriteria pada Tabel 4.

Tabel 4. Pedoman konversi interval persentase menjadi kategori

\begin{tabular}{cc}
\hline Persentase $(\%)$ & Kategori \\
\hline $81-100$ & Sangat baik \\
$61-80$ & Baik \\
$41-60$ & Cukup \\
$21-40$ & Kurang \\
$0-20$ & Sangat kurang \\
\hline
\end{tabular}

5) Menghitung gain score, besarnya peningkatan sebelum dan sesudah perlakuan dihitung dengan rumusan gain ternormalisasi.

$$
\mathrm{g}(\text { gain tern ormalisasi })=\frac{\text { Skor }_{\text {Postes }}-\text { Skor }_{\text {Pretes }}}{\text { Skor }_{\text {maximum }}-\text { Skor }_{\text {pretes }}}
$$

Klasifikasi gain ternormalisasi terlihat pada Tabel 5 .

Tabel 5. Klasifikasi gain ternormalisasi

\begin{tabular}{cc}
\hline Koefisien normalisasi gain & Klasifikasi \\
\hline $\mathrm{g}<0,3$ & Rendah \\
$0,3 \leq \mathrm{g}<0,7$ & Sedang \\
$\mathrm{g} \geq 0,7$ & Tinggi \\
\hline
\end{tabular}

\section{Analisis Inferensial}

Teknik statistika inferensial digunakan untuk menguji hipotesis penelitian yang telah dirumuskan sebelumnya. Uji hipotesis dilakukan untuk dapat melihat adanya peningkatan kecakapan kolaboratif siswa sebelum dan setelah perlakuan diberikan. Uji hipotesis yang digunakan adalah one sample t-test. Hipotesis dirumuskan dalam bentuk hipotesis statistik sebagai berikut (Arikunto, 2004):

$\mathrm{H}_{0}: \mu_{B} \leq 0,29$

$\mathrm{H}_{1}: \mu_{B}>0,29$

Dimana, $\mu_{B}=$ parameter selisih rata-rata hasil gain ternormalisasi tes kecakapan kolaboratif siswa kelas VI SD YPS Singkole sebelum dan setelah diterapkan pembelajaran matematika berbasis 
google suite for education. Perhitungan dilakukan dengan bantuan program aplikasi SPSS versi 24.0 (statistica product and service solution). Kriteria pengambilan keputusan yaitu:

a. Jika taraf signifikansi $\mathrm{p} \geq 0,05$ maka $\mathrm{H}_{0}$ diterima, dan $\mathrm{H}_{1}$ ditolak artinya tidak terdapat peningkatan kecakapan kolaboratif siswa sebelum dan setelah perlakuan.

b. Jika taraf signifikansi $\mathrm{p}<0,05$ maka $\mathrm{H}_{0}$ ditolak dan $\mathrm{H}_{1}$ diterima, artinya terdapat peningkatan kecakapan kolaboratif siswa sebelum dan setelah perlakuan.

\section{HASIL DAN PEMBAHASAN \\ Hasil Analisis Deskriptif}

1. Hasil observasi aktivitas siswa pada pembelajaran matematika berbasis google suite for education Indikator aktivitas siswa terdiri dari 11 aspek observasi yang didasarkan pada karakteristik pembelajaran yang diterapkan, yaitu: (1) siswa memperhatikan penjelasan guru; (2) siswa memanfaatkan media pembelajaran berupa fitur-fitur pada google suite for education; (3) siswa membaca dan memahami materi pada google classroom; (4) keaktifan siswa dalam diskusi kelompok secara langsung maupun memanfaatkan media yang tersedia; (5) siswa bekerjasama dalam menyelesaikan lembar kerja secara berkelompok melalui google document; (6) siswa mempresentasikan hasil kerja kelompok dan menanggapi jawaban kelompok lain; (7) siswa mengerjakan kuis secara mandiri melalui google form; (8) siswa membuat kesimpulan pembelajaran melalui google form; (9) siswa dapat memecahkan masalah pada latihan soal yang diberikan; (10) siswa dapat mengolah informasi dan konsep yang telah diperoleh untuk menyelesaikan soal latihan; dan (11) siswa tidak melakukan kegiatan lain di luar pembelajaran misalnya bermain game dan mengganggu teman. Rangkuman hasil observasi aktivitas siswa disajikan pada Tabel 6.

Tabel 6. Rekapitulasi hasil observasi aktivitas siswa

\begin{tabular}{|c|c|c|c|c|c|c|}
\hline \multirow{2}{*}{ Aspek yang diamati } & \multicolumn{4}{|c|}{ Skor aktivitas tiap pertemuan } & \multirow{2}{*}{$\begin{array}{c}\text { Rata-rata } \\
\text { aktivitas siswa }\end{array}$} & \multirow{2}{*}{ Kategori } \\
\hline & P1 & P2 & P3 & P4 & & \\
\hline 1 & 4 & 4 & 5 & 5 & 4,50 & Sangat Aktif \\
\hline 2 & 4 & 4 & 4 & 5 & 4,25 & Aktif \\
\hline 3 & 4 & 4 & 5 & 5 & 4,50 & Sangat Aktif \\
\hline 4 & 4 & 4 & 4 & 4 & 4,00 & Aktif \\
\hline 5 & 4 & 4 & 4 & 5 & 4,25 & Aktif \\
\hline 6 & 3 & 4 & 4 & 4 & 3,75 & Aktif \\
\hline 7 & 4 & 4 & 5 & 5 & 4,50 & Sangat Aktif \\
\hline 8 & 3 & 4 & 4 & 5 & 4,00 & Aktif \\
\hline 9 & 4 & 4 & 5 & 5 & 4,50 & Sangat Aktif \\
\hline 10 & 3 & 4 & 5 & 5 & 4,25 & Aktif \\
\hline 11 & 5 & 5 & 5 & 5 & 5,00 & Sangat Aktif \\
\hline Rata-rata & 3,82 & 4,09 & 4,55 & 4,82 & 4,32 & Aktif \\
\hline
\end{tabular}

Berdasarkan Tabel 6 menunjukkan kategori aktivitas siswa pada semua aspek yang diamati minimal berada pada kategori aktif $(3,5 \leq \bar{x}<4,5)$ berdasarkan Tabel 1 .

2. Hasil observasi keterlaksanaan pembelajaran matematika berbasis google suite for education

Hasil observasi terhadap keterlaksanaan pembelajaran selama empat kali pertemuan disajikan pada Tabel 7.

Tabel 7. Rekapitulasi hasil observasi keterlaksanaan pembelajaran

\begin{tabular}{|c|c|c|c|c|c|c|c|}
\hline \multirow{2}{*}{ No } & \multirow{2}{*}{ Aspek } & \multicolumn{4}{|c|}{ Pertemuan } & \multirow{2}{*}{$\begin{array}{c}\text { Rata-rata } \\
\text { keterlaksanaan }\end{array}$} & \multirow{2}{*}{ Kriteria } \\
\hline & & 1 & 2 & 3 & 4 & & \\
\hline 1 & Kegiatan pendahuluan & 100 & 100 & 100 & 100 & 100 & Sangat baik \\
\hline 2 & Kegiatan inti & 92,5 & 100 & 100 & 100 & 98,13 & Sangat baik \\
\hline 3 & Kegiatan penutup & 100 & 100 & 100 & 100 & 100 & Sangat baik \\
\hline \multicolumn{6}{|c|}{ Skor rata-rata } & 99,38 & Sangat baik \\
\hline
\end{tabular}

Berdasarkan Tabel 7, diperoleh hasil bahwa rata-rata keterlaksanaan pembelajaran berada pada kategori sangat baik. 
3. Hasil angket respon siswa terhadap pembelajaran matematika berbasis google suite for education

Hasil pengisian angket respon siswa terhadap pembelajaran matematika berbasis google suite for education dapat dilihat pada Tabel 8.

Tabel 8. Hasil respon siswa terhadap pembelajaran

\begin{tabular}{clcc}
\hline No & \multicolumn{1}{c}{ Aspek } & $\begin{array}{c}\text { Rata-rata } \\
\text { respon siswa }\end{array}$ & Kriteria \\
\hline 1 & Sikap siswa terhadap pembelajaran & 3,52 & Positif \\
2 & Minat dan semangat siswa dalam mengikuti pembelajaran & 3,56 & Positif \\
3 & Keterkaitan pembelajaran terhadap kemampuan matematis siswa & 3,54 & Positif \\
4 & Penggunaan media dalam pembelajaran & 3,58 & Positif \\
5 & Menumbuhkan kreativitas dan kerjasama siswa & 3,51 & Positif \\
& Rata-rata total & 3,54 & Positif \\
\hline
\end{tabular}

Berdasarkan Tabel 8 diperoleh informasi bahwa rata-rata total skor respon siswa terhadap pembelajaran matematika berbasis google suite for education adalah 3,54 dengan kriteria positif.

4. Hasil analisis statistik deskriptif observasi awal kecakapan kolaboratif siswa

Hasil analisis deskriptif terhadap nilai observasi awal kecakapan kolaboratif siswa disajikan pada Tabel 9.

Tabel 9. Statistik deskriptif skor observasi awal kecakapan kolaboratif siswa

\begin{tabular}{cc}
\hline Statistik & Nilai statistik observasi awal \\
\hline Ukuran sampel & 30 \\
Nilai ideal & 100 \\
Nilai tertinggi & 82 \\
Nilai terendah & 20 \\
Rentang nilai & 62 \\
Nilai rata-rata & 55,89 \\
Variansi & 351,02 \\
Standar deviasi & 18,74 \\
\hline
\end{tabular}

Konversi nilai observasi awal kecakapan kolaboratif siswa disajikan pada Tabel 10.

Tabel 10. Distribusi frekuensi hasil observasi awal kecakapan kolaboratif siswa

\begin{tabular}{cccc}
\hline \multirow{2}{*}{ Persentase kecakapan kolaboratif } & \multirow{2}{*}{ Kriteria } & \multicolumn{2}{c}{ Observasi awal } \\
\cline { 3 - 4 } & Sangat baik & Frekuensi & Persentase (\%) \\
\hline $81-100$ & Baik & 12 & 6,67 \\
$61-80$ & Cukup & 10 & 40 \\
$41-60$ & Rendah & 3 & 33,33 \\
$21-40$ & Sangat rendah & 3 & 10 \\
$0-20$ & & 30 & 10 \\
& Total & & 100 \\
\hline
\end{tabular}

Berdasarkan Tabel 9 dan Tabel 10 diperoleh bahwa nilai rata-rata observasi awal kecakapan kolaboratif siswa adalah 55,89 dengan standar deviasi 18,74 dari nilai ideal 100 berada pada kategori cukup. Hal ini menunjukkan bahwa kecakapan kolaboratif siswa masih perlu untuk dikembangkan dalam seluruh aspek yang diamati. Analisis data berdasarkan aspek-aspek kecakapan kolaboratif yang diukur disajikan pada Tabel 11.

Tabel 11. Rata-rata nilai tiap aspek hasil obeservasi awal kecakapan kolaboratif

\begin{tabular}{clcc}
\hline No & \multicolumn{1}{c}{ Aspek } & Rata-rata nilai tiap aspek & Kriteria \\
\hline 1 & Percaya diri & 54,83 & Cukup \\
2 & Sikap positif & 59,05 & Cukup \\
3 & Menghargai & 56,67 & Cukup \\
4 & Memberikan dorongan & 51,33 & Cukup \\
5 & Membangun semangat kelompok & 53,50 & Cukup \\
\hline
\end{tabular}

Berdasarkan Tabel 11, dapat dilihat bahwa secara keseluruhan dari lima aspek yang diukur, rata-rata nilai setiap aspek berada pada kategori cukup, artinya dari segi kecakapan kolaboratif siswa masih perlu untuk dikembangkan. 
5. Hasil analisis statistik deskriptif observasi akhir kecakapan kolaboratif siswa

Hasil analisis deskriptif terhadap nilai observasi akhir kecakapan kolaboratif siswa disajikan pada Tabel 12.

Tabel 12. Statistik deskriptif skor observasi akhir kecakapan kolaboratif siswa

\begin{tabular}{cc}
\hline Statistik & Nilai statistik observasi akhir \\
\hline Ukuran sampel & 30 \\
Nilai ideal & 100 \\
Nilai tertinggi & 98 \\
Nilai terendah & 80 \\
Rentang nilai & 18 \\
Nilai rata-rata & 93,28 \\
Variansi & 29,55 \\
Standar deviasi & 5,44 \\
\hline
\end{tabular}

Konversi nilai observasi akhir kecakapan kolaboratif siswa setelah penerapan pembelajaran matematika berbasis google suite for education disajikan pada Tabel 13.

Tabel 13. Distribusi frekuensi hasil observasi akhir kecakapan kolaboratif siswa

\begin{tabular}{cccc}
\hline \multirow{2}{*}{ Persentase kecakapan kolaboratif } & Kriteria & \multicolumn{2}{c}{ Observasi akhir } \\
& & Frekuensi & Persentase (\%) \\
\hline $81-100$ & Sangat Baik & 28 & 93,33 \\
$61-80$ & Baik & 2 & 6,67 \\
$41-60$ & Cukup & 0 & 0 \\
$21-40$ & Rendah & 0 & 0 \\
$0-20$ & Sangat Rendah & 0 & 0 \\
\hline & & 30 & 100 \\
\hline
\end{tabular}

Berdasarkan Tabel 12 dan Tabel 13 diperoleh bahwa nilai rata-rata observasi akhir kecakapan kolaboratif siswa adalah 93,28 dengan standar deviasi 5,44 dari nilai ideal 100 berada pada kategori sangat baik. Analisis data berdasarkan aspek-aspek kecakapan kolaboratif yang diukur disajikan pada Tabel 14.

Tabel 14. Rata-rata nilai tiap aspek hasil obeservasi akhir kecakapan kolaboratif

\begin{tabular}{clcc}
\hline No & \multicolumn{1}{c}{ Aspek } & Rata-rata nilai tiap aspek & Kriteria \\
\hline 1 & Percaya diri & 92,67 & Sangat baik \\
2 & Sikap positif & 93,62 & Sangat baik \\
3 & Menghargai & 93,52 & Sangat baik \\
4 & Memberikan dorongan & 92,22 & Sangat baik \\
5 & Membangun semangat kelompok & 93,67 & Sangat baik \\
\hline
\end{tabular}

Berdasarkan Tabel 14, dapat dilihat bahwa secara keseluruhan dari lima aspek yang diukur, rata-rata nilai setiap aspek berada pada kategori sangat baik, artinya dari segi kecakapan kolaboratif siswa mengalami peningkatan yang signifikan jika dibandingkan dengan kecakapan kolaboratif pada observasi awal.

6. Hasil analisis statistik deskriptif gain ternormalisasi kecakapan kolaboratif siswa

Berdasarkan data hasil observasi awal dan observasi akhir berkaitan dengan kecakapan kolaboratif siswa, maka selanjutnya dilakukan analisis nilai gain terhadap peningkatan kecakapan kolaboratif siswa. Hasil analisis nilai gain disajikan pada Tabel 15.

Tabel 15. Statistik deskriptif peningkatan nilai observasi awal ke observasi akhir kecakapan kolaboratif siswa

\begin{tabular}{cc}
\hline Statistik & Nilai statistik \\
\hline Ukuran sampel & 30 \\
Nilai ideal & 1,00 \\
Nilai tertinggi & 0,97 \\
Nilai terendah & 0,55 \\
Rentang nilai & 0,41 \\
Nilai rata-rata & 0,84 \\
Variansi & 0,015 \\
Standar deviasi & 0,121 \\
\hline
\end{tabular}


Klasifikasi nilai gain ternormalisasi kecakapan kolaboratif siswa disajikan pada Tabel 16.

Tabel 16. Klasifikasi gain ternormalisasi kecakapan kolaboratif siswa

\begin{tabular}{|c|c|c|c|}
\hline Koefisien normalisasi gain & Klasifikasi & Frekuensi & Persentase (\%) \\
\hline $\mathrm{g}<0,3$ & Rendah & 0 & 0 \\
\hline $0,3 \leq \mathrm{g}<0,7$ & Sedang & 5 & 16,67 \\
\hline$g \geq 0,7$ & Tinggi & 25 & 83,33 \\
\hline Total & & 30 & 100 \\
\hline
\end{tabular}

Berdasarkan Tabel 15 dan Tabel 16 diperoleh bahwa nilai rata-rata peningkatan kecakapan kolaboratif siswa dengan menerapkan pembelajaran matematika berbasis google suite for education yaitu sebesar 0,84 dengan standar deviasi 0,015 dari skor ideal 1 berada pada klasifikasi tinggi. Siswa mengalami peningkatan yang cukup signifikan dalam hal kecakapan bekerjasama (berkolaborasi) dengan penerapan pembelajaran matematika berbasis google suite for education.

\section{Hasil Analisis Statistik Inferensial}

Analisis statistik inferesial kecakapan kolaboratif siswa sebagai berikut:

1. Uji normalitas

Hasil uji normalitas kecakapan kolaboratif siswa menunjukkan bahwa nilai probabilitas pretest kecakapan kolaboratif adalah $0,149>0,05$ dan nilai probabilitas posttest kecakapan kolaboratif adalah $0,077>0,05$. Artinya dapat disimpulkan bahwa data pretest dan posttest kecakapan kolaboratif siswa berdistribusi normal.

\section{Uji hipotesis}

Pengujian hipotesis yaitu dengan uji-t menggunakan one sample T-test. Berdasarkan hasil paired samples test menunjukkan bahwa Sig. (2-tailed) sebesar 0,000 $<0,05$. Hal ini berarti bahwa $\mathrm{H}_{0}$ ditolak dan $\mathrm{H}_{1}$ diterima yaitu gain ternormalisasi kecakapan kolaboratif siswa yang mengikuti pembelajaran matematika berbasis google suite for education secara signifikan lebih besar dari 0,29. Sehingga dapat dikatakan terjadi peningkatan kecakapan kolaboratif setelah penerapan pembelajaran matematika berbasis google suite for education.

\section{Pembahasan}

\section{Aktivitas Siswa}

Keaktifan siswa tergambar dalam kegiatan pembelajaran secara langsung (singkron) maupun kegiatan pembelajaran online (asingkron), yaitu:

a. Pembelajaran langsung secara virtual (singkron)

Aktivitas siswa dalam kegiatan pembelajaran matematika langsung secara virtual berbasis google suite for education, yaitu: (1) tepat waktu dalam kehadiran pada pertemuan virtual, serta mengisi daftar hadir; (2) antusias dalam memperhatikan penjelasan guru yang dikemas dalam media google slide, diintegrasikan dengan video pembelajaran, video motivasi, gambar dan audio; (3) terlibat aktif dalam memanfaatkan media pembelajaran berupa fitur dalam google suite for education, misalnya google meet, google document, dan jamboard; (4) aktif bekerja dalam kelompok menggunakan google document dengan berbagai fasilitas yang dapat siswa gunakan didalamnya, seperti menu explore, komentar, chat, dan kolaborasi menulis dan mengedit pekerjaan kelompok secara bersama secara real time; (5) guru menggunakan jamboard bukan hanya sebagai papan tulis online tetapi juga mengajak siswa berkolaborasi mengerjakan contoh soal secara bersama-sama; (6) menyelesaikan tugas mandiri dan membuat kesimpulan pembelajaran pada google form dengan baik; dan (7) seluruh peserta fokus, tidak mengganggu dan mematuhi aturan kelas serta tidak melakukan kegiatan lain diluar pembelajaran.

b. Pembelajaran mandiri secara online (asingkron)

Aktivitas siswa dalam kegiatan pembelajaran matematika mandiri secara online berbasis google suite for education, yaitu: (1) mengkonfirmasi kehadiran pertemuan melalui pemberitahuan di email yang dikirim melalui goolge calender; (2) aktif dalam mengunjungi classroom, disana siswa dapat membaca materi, menonton video pembelajaran, berkomentar, bertanya dan berdiskusi dengan 
teman maupun guru; (3) inisiatif melakukan chatting melalui hangouts untuk mengatur jadwal dengan teman kelompok untuk menyelesaikan tugas kelompok asingkron yang diberikan; (4) menyelesaikan dengan baik tugas kelompok asingkron yang diberikan, dimana aktivitas diskusi dan kerja kelompok yang siswa lakukan terekam dalam google document.

Diantara aspek yang diamati, beberapa hal yang perlu ditingkatkan diantaranya dalam hal keaktifan siswa dalam berdiskusi dalam kelompok. Beberapa siswa masih terlihat canggung untuk mengemukakan pendapat apalagi secara langsung. Siswa lebih merasa nyaman untuk menuliskan pendapat atau jawabannya pada kolom chat dan komentar. Bahkan dipertemuan awal, terdapat 1 kelompok yang harus dipandu oleh guru langkah demi langkah. Namun, diskusi kelompok berjalan dengan baik dan sudah mulai melibatkan semua anggota dalam kelompok, walaupun masih ada anggota kelompok yang belum percaya diri dan masih dalam taraf penyesuaian menggunakan fasilitas google suite for education.

Aspek mempresentasikan hasil kerja kelompok juga merupakan aspek yang masih perlu ditingkatkan. Diantara semua aspek yang diamati, mempresentasikan hasil kerja kelompok menjadi aspek dengan nilai rata-rata terendah yakni sebesar 3,75 pada skor ideal 5. Meskipun presentasi dilakukan secara bergiliran dan setiap kelompok diberi kesempatan, namun masih ada monopoli oleh siswa tertentu saja yang berani untuk mempresentasikan dan memberikan tanggapan, sehingga guru perlu memberikan stimulus lebih untuk meransang anak berani mengemukakan ide dan gagasannya.

Keaktifan siswa dalam pembelajaran meningkat dari awal hingga akhir pertemuan. Rata-rata skor aktivitas siswa pada pertemuan ke-1 hanya sebesar 3,82, kemudian meningkat pada pertemuan ke-2 sebesar 4,09, pertemuan ke-3 sebesar 4,55 dan puncaknya pada pertemuan ke-4 sebesar 4,82. Hal ini menunjukkan bahwa semakin sering siswa melakukan aktivitas pembelajaran yang dirancang, maka siswa semakin terbiasa dan menyesuaikan diri. Siswa yang awalnya canggung untuk menggunakan media yang digunakan akhirnya terbiasa, awalnya malu untuk mengemukakan pendapat akhirnya mulai berani mengemukakan idenya, apalagi ditunjang dengan fasilitas chat dan komentar. Sehingga siswa dapat berkomunikasi dengan lebih fleksibel, bukan hanya komunikasi secara lisan, namun siswa dapat mengemukakan pendapat secara tertulis. Hasil analisis menunjukkan kesimpulan bahwa aktivitas siswa saat diterapkan pembelajaran berbasis google suite for education dalam pembelajaran matematika dengan rata-rata 4,32 berada pada kategori aktif dengan kriteria aktivitas siswa yaitu $3,5 \leq \bar{x}<4,5$.

\section{Keterlaksanaan Pembelajaran}

Materi ajar dalam penelitian ini adalah materi kelas VI bab pengolahan data. RPP yang telah disusun menjadi acuan dalam pelaksanaan pembelajaran baik pertemuan secara singkron maupun asingkron. Pembelajaran face to face dapat dilakukan secara virtual (pertemuan singkron) dengan memanfaatkan fasilitas google meet, jamboard sebagai papan tulis online, penampilan materi melalui google slide, diskusi kelompok dan kolaborasi dengan goolge document dan dapat diamati dan dibimbing langsung oleh guru selaku peneliti.

Secara keseluruhan langkah-langkah pembelajaran pada pertemuan virtual (singkron) terlaksana dengan sangat baik. Namun pada pertemuan ke-1, observer mengamati bahwa ada sedikit langkah yang terlupa yaitu guru tidak memberi kesempatan kepada siswa untuk bertanya tentang hal yang belum jelas, serta siswa kurang diberi waktu untuk mengeksplor materi dan bahan pelajaran yang telah di upload pada classrorom. Pada pertemuan ke-1 ini juga terdapat 1 kelompok kurang terdampingi dengan baik oleh guru, sehingga kurang maksimal dalam diskusi kelompoknya. Sementara pada pertemuan ke-2, ke-3 dan ke-4 semua proses dan langkah pembelajaran telah terlaksana dengan baik.

Pembelajaran online secara mandiri (asingkron) yang dilakukan guru juga dapat dipantau melalaui instruksi-instruksi dan tanggapan yang diberikan pada forum di classroom, hangouts, maupun komentar pada penugasan asingkron dengan google document. Materi dalam bentuk google slide, video pembelajaran, rekaman pembelajaran serta penugasan dalam bentuk google document 
dijadwalkan dengan rapih pada classroom sesuai dengan topik masing-masing. Siswa dapat mengakses dengan mudah kapan dan dimanapun siswa memiliki kesempatan dan dapat disesuaikan dengan kebutuhan.

Kelebihan dari fitur-fitur google suite for education dalam pembelajaran matematika berbasis google suite for education adalah: (1) pengaturan jadwal dengan google calender memudahkan siswa dalam bergabung dengan pertemuan virtual, siswa tidak perlu meminta akses jika ingin bergabung dengan pertemuan, karena sudah dijadwalkan melalui google calender dan terkirim langsung ke email siswa; (2) pelaksanaan pembelajaran secara virtual dengan google meet memudahkan interaksi dengan siswa dalam menyampaikan materi, diskusi dan tanya jawab, pemberian motivasi, instruksi serta pendampingan siswa dalam kerja kelompok dan mempresentasikan hasil diskusi kelompok dengan share screen; (3) pengaturan materi, video pembelajaran, rekaman pembelajaran, dan penugasan di classroom memudahkan siswa dalam mempelajarai materi secara mandiri kapan dan dimanapun serta dapat diakses sesuai kebutuhan siswa; (4) diskusi dan instruksi pada forum di classrooom dan hangouts juga dapat mengarahkan siswa dalam belajar secara mandiri; (5) materi yang disajikan dalam google slide mudah diintegrasikan dengan video dan konten menarik; (6) penggunaaan jamboard sebagai papan tulis online dan juga dapat berkolaborasi dengan siswa dalam kelompok masing-masing; (7) penugasan dalam bentuk google document memudahkan guru mengawasi siswa dalam kolaborasi, mencari sumber materi dengan menu explore, serta diskusi melalui chat dan komentar; (8) tugas mandiri dan kesimpulan pembelajaran efektif diberikan dalam bentuk google formulir, dan (9) semua file tersusun rapi dan tersimpan secara otomatis dalam penyimpanan cloud dengan google drive.

Beberapa kendala dalam pelaksanaan pembelajaran online khususnya pertemuan virtual (singkron) adalah: (1) jaringan internet yang tidak stabil; (2) perangkat yang tidak support sehingga dibackup dengan menggunakan gawai; dan (3) pendampingan diskusi secara bergilir mengharuskan guru bolak balik dari room meeting setiap kelompok sehingga kelompok harus bersabar menunggu guru datang.

\section{Respon Siswa}

Siswa menunjukkan sikap positif dalam pembelajaran matematika berbasis goolge suite for education. Siswa merasa difasilitasi dalam belajar sehingga siswa mengetahui tujuan pembelajaran dan garis besar materi pembelajaran. Selain itu, pembelajaran yang ditunjang dengan kegiatan belajar online diluar tatap muka membantu siswa dalam memahami materi lebih mendalam, mereka menemukan pengetahuan-pengetahuan baru diluar pertemuan virtual yang dapat mereka akses kapan dan dimana saja tanpa terbatas ruang dan waktu. Dengan rutin mengunjungi classroom dan sumber belajar online lainnya, mereka dapat memecahkan masalah dan dapat bertanya tentang kesulitan yang mereka hadapi.

Minat dan semangat siswa dalam mengikuti pembelajaran juga berada pada kategori positif. Siswa senang dan antusias mengikuti pembelajaran, mereka merasa pembelajaran lebih bervariasi, menarik dan seru dengan memadukan berbagai keterampilan dalam proses pembelajaran. Siswa bersemangat dan merasa nyaman bekerja dalam kelompok, berdiskusi, percaya diri dalam mengajukan pertanyaan, dan mempresentasikan hasil diskusi. Pembelajaran matematika berbasis gogole suite for education sangat membantu mengkonstruksi pemahaman siswa. Bahan ajar yang ditampilkan di google classroom serta sumber belajar online lainnya membuat siswa lebih mudah memahami materi pelajaran, bebas mencari materi dan wawasan baru, serta menemukan hal-hal baru untuk meningkatkan pemahaman siswa dan dapat membantu menyelesaikan masalah mereka. Ditambah lagi dengan pendampingan siswa saat belajar tatap muka mengantarkan siswa pada pemahaman yang baik.

Pembelajaran matematika berbasis goolge suite for education menarik dan bervariasi, sehingga siswa dapat memahami materi dan menyelesaikan tugas. Siswa lebih mengerti menggunakan aplikasi dan fasilitas dari google dengan baik dan benar, serta mudah dalam berkolaborasi dan berkomunikasi. Siswa lebih menghargai ide dan gagasan temannya, termotivasi 
untuk mencari sumber-sumber penunjang yang dapat mendukung ide-ide baru dalam kerja kelompok, dan dapat menumbuhkan ide-ide kreatif siswa. Hal ini senada dengan pendapat Zakiah (2020) bahwa diantara berbagai faktor yang dapat meningkatkan prestasi siswa adalah kemampuan menyusun rencana berdasarkan informasi yang ada, kemampuan menyusun strategi penyelesaian masalah, serta mengetahui alasan pemilihan strategi penyelesaian tersebut.

\section{Kecakapan Kolaboratif}

Dalam pembelajaran matematika berbasis google suite for education, aktivitas kelompok dapat diamati dalam pembelajaran tatap muka secara virtual melalui google meet secara langsung, maupun melalui chat dan komentar pada google document lembar kerja siswa. Sementara pada pembelajaran online asingkron, aktivitas kelompok dapat diamati melalui hangouts, forum classroom dan juga lembar kerja google document. Penjelasan mengenai indikator yang diukur terkait kecakapan kolaboratif sebagai berikut:

a. Percaya Diri

Diskusi dan kerjasama yang dilakukan siswa dalam pembelajaran matematika berbasis goolge suite for education terlihat dalam usaha dan kemauan mereka menyampaikan ide dan saran serta mencari sumber referensi bahan diskusi. Siswa juga lebih percaya diri secara mandiri melakukan kegiatan diskusi baik dalam kegiatan pembelajaran tatap muka maupun dalam menyelesaikan diskusi kelompok secara online diluar jam tatap muka.

\section{b. Sikap Positif}

Siswa menunjukkan sikap positif ketika bekerja dalam kelompoknya, saling menghargai kemampuan dan peran setiap anggota kelompok. Siswa berbicara secara positif dengan kata-kata yang baik dan tidak keluar dari konteks diskusi, komunikasi dilakukan secara lisan maupun tertulis melalui kolom komentar dan chat. Setiap siswa berperan aktif dalam kegiatan kelompok karena dapat langsung bekerja dan mengedit secara bersamaan pada Lembar Kerja Peserta Didik (LKPD) yang dibuat dalam file google document dan juga melakukan pencarian dengan menu explore pada google document.

c. Menghargai

Saling menghargai antar anggota kelompok menjadi hal yang penting untuk kelancaran kegiatan diskusi dan penyelesaian tugas kelompok. Terlihat bahwa siswa mau mendengarkan dan memikirkan pendapat anggota kelompok sebelum memberi saran, mau belajar dari anggota kelompok lainnya. Siswa yang kurang mengerti tidak malu untuk bertanya, demikian juga anggota kelompok yang telah mengerti bersedia menjelaskan kepada temannya. Artinya bahwa siswa saling menghargai kemampuan masing-masing. Dalam hal pengambilan keputusan, siswa melibatkan semua anggota kelompok.

d. Memberi Dorongan

Siswa mampu berkolaborasi dengan sangat baik dalam kelompok. Mau membantu teman yang kurang memahami materi dan mampu memberdayakan anggota kelompoknya dalam menyelesaikan masalah. Siswa juga saling memberi pujian kepada anggota tim yang bekerja dengan baik, dan senantiasa membangun kekompakan dan membuat anggota tim merasa penting, berguna dan memiliki perannya masing-masing.

e. Membangun Semangat Kelompok

Semangat kebersamaan dalam kelompok dibangun dengan baik, siswa sigap membantu teman yang kurang memahami materi dan mampu menciptakan suasana diskusi yang akrab dan menarik bagi semua anggota kelompok. Menciptakan suasana kondusif, moral kerja yang baik dan tidak menyalahkan anggota tim. Meminimalisir perselisihan dalam kelompok, serta saling membantu dalam menjawab pertanyaan dari kelompok lain.

Hasil penelitian ini diperkuat dengan penelitian yang menunjukkan bahwa salah satu manfaat pembelajaran kolaboratif dalam melaksanakan tugas secara berkelompok adalah membantu siswa yang lemah untuk membangun kepercayaan diri (Zakiah et al., 2020). Selanjutnya, penelitian ini sejalan dengan hasil penelitian dari Supianti (2016) dan Kusuma (2020) yang menyatakan bahwa e- 
learning pada PJJ dapat meningkatkan kemandirian belajar, membuat siswa lebih aktif, lebih tertarik dan lebih termotivasi untuk belajar.

\section{KESIMPULAN}

Kesimpulan dari penelitian ini adalah: (1) aktivitas siswa dalam pembelajaran matematika berbasis goolge suite for education berada pada kategori aktif; (2) keterlaksanaan pembelajaran matematika berbasis goolge suite for education berada pada kategori terlaksana dengan sangat baik; (3) respon siswa terhadap pembelajaran matematika berbasis goolge suite for education berada pada kategori positif; (4) kecakapan kolaboratif siswa kelas VI SD YPS Singkole Tahun Pelajaran 2020/2021 pada pembelajaran matematika berbasis goolge suite for education berada pada kategori sangat baik; dan (5) pembelajaran matematika berbasis goolge suite for education dapat meningkatkan kecakapan kolaboratif siswa kelas VI SD YPS Singkole Tahun Pelajaran 2020/2021, berada pada kategori tinggi.

\section{REKOMENDASI}

Rekomendasi dari penelitian ini yaitu pembelajaran matematika berbasis gogole suite for education dengan penggabungan antara pembelajaran tatap muka virtual (singkron) dan pembelajaran mandiri secara online (asingkron) dapat menjadi salah satu rekomendasi pembelajaran bagi guru untuk meningkatkan kecakapan kolaboratif.

\section{UCAPAN TERIMA KASIH}

Peneliti mengucapkan terima kasih kepada pihak kampus Universitas Cokroaminoto Palopo yang telah memberikan bimbingan dan pendampingan dalam melakukan penelitian ini. Ucapan terima kasih juga kami sampaikan kepada pihak sekolah SD YPS Singkole.

\section{DAFTAR PUSTAKA}

Arikunto, S. (2004). Prosedur penelitian (suatu pendekatan praktik). Jakarta: Rineka Cipta.

Arsyad, N. (2016). Model pembelajaran menumbuhkembangkan kemampuan metakognitif. Makassar: Pustaka Refleksi.

Cholily, Y. M., Putri, W. T., \& Kusgiarohmah, P. A. (2019). Pembelajaran di era revolusi industri 4.0. Seminar Nasional Penelitian Pendidikan Matematika (SNP2M), 192.

Gunawan, F. I., \& Sunarman, S. G. (2018). Pengembangan kelas virtual dengan google classroom dalam keterampilan pemecahan masalah (problem solving) topik vektor pada siswa smk untuk mendukung pembelajaran. Prosiding Seminar Nasional Etnomatnesia, 340-348.

Hasbullah. (2014). Blended learning, trend strategi pembelajaran matematika masa depan. Jurnal Formatif, 4(1), 65-70. Doi: https://doi.org/10.30998/formatif.v4i1.140.

Hermawan., Siahaan, P., Suhendi, E., Kaniawati, I., Samsudin, A., Setyadin, A. H., \& Hidayat, S. R. (2017). Desain rubrik kemampuan berkolaborasi siswa smp dalam materi pemantulan cahaya. Jurnal Penelitian \& Pengembangan Pendidikan Fisika (JPPPF), 3(2), 167-174. Doi: https://doi.org/10.21009/1.03207.

Herrick, D. R. (2010). Google this! using google apps for collaboration and productivity. Colorado State University, 55-63.

Izza, J. (2019). Mengawali integritas era digital 2019. Buletin APJII, 5. 
Kusuma, D. A. (2020). Dampak penerapan pembelajaran daring terhadap kemandirian belajar (selfregulated learning) mahasiswa pada mata kuliah geometri selama pembelajaran jarak jauh di masa pandemi covid-19. Teorema: Teori dan Riset Matematika, 5(2), 169-175. Doi: DOI: http://dx.doi.org/10.25157/teorema.v5i2.3504.

Latip, A. (2020). Peran literasi teknologi informasi dan komunikasi pada pembelajaran jarak jauh (pjj) di masa pandemi covid-19. Jurnal Edukasi dan Teknologi Pembelajaran, 1(2), 107-115. Doi: https://doi.org/10.37859/eduteach.v1i2.1956.

Riasari, D. (2018). Peranan model pembelajaran matematika berbasis blended learning terhadap komunikasi matematis siswa dalam materi statistik pada sman 1 tapung. Jurnal Pendidikan Tambusai, 2(2), 813-820. Doi: https://doi.org/10.31004/jptam.v2i4.28.

Risdianto, E. (2019). Analisis pendidikan indonesia di era revolusi industri 4.0. Universitas Bengkulu.

Supianti, I. I. (2016). Dampak penerapan e-learning dalam pembelajaran matematika terhadap kemandirian belajar mahasiswa. Teorema: Jurnal Teori dan Riset matematika, 1(1).

Wijaya, E. Y., Sudjimat, D. A., \& Nyoto, A. (2016). Transformasi pendidikan abad 21 sebagai tuntutan pengembangan sumber daya manusia di era global. Prosiding Seminar Nasional Pendidikan Matematika 2016 Universitas Kanjuruhan Malang, 1, 263-278.

Zakiah, N. E. (2020). Level kemampuan metakognitif siswa dalam pembelajaran matematika berdasarkan gaya kognitif. Jurnal Riset Pendidikan Matematika, 7(2), 132-147. Doi: https://doi.org/10.21831/jrpm.v7i2.30458.

Zakiah, N. E., Fatimah, A. T., Sunaryo, Y., \& Amam, A. (2020). Collaboration and communication skills of pre-service mathematics teacher in designing project assignments. J. Phys.: Conf. Ser. 1657 012073. doi:10.1088/1742-6596/1657/1/012073. 